\title{
Aflatoxins and fumonisins in feed from a broiler operation system from São Paulo state, Brazil
}

\section{Estela Kobashigawa ${ }^{1}$ Carlos Humberto Corassin ${ }^{2}$ iD Larissa Tuanny Franco ${ }^{2}$ Rômulo Dutra Uliana ${ }^{2}$ iD Carlos Augusto Fernandes de Oliveira ${ }^{2^{*}}$ (iD)}

${ }^{1}$ Division of Animal Sciences, University of Missouri, Columbia, MO, United States

${ }^{2}$ Departamento de Engenharia de Alimentos, Faculdade de Zootecnia e Engenharia de Alimentos, Universidade de São Paulo (USP), 13635-900, Pirassununga, SP, Brasil. E-mail: carlosf@usp.br. "Corresponding author.

ABSTRACT: The aim of the present study was to assess the occurrence of aflatoxins (AFs) and fumonisins (FBs) in feed ingredients (corn and soybean meal) and finishing feed in a broiler operation system, as well was to evaluate their effect on the productivity of 20 batches of broilers produced and the histology status of broilers' liver after slaughter. Corn samples presented the highest frequencies of AFs and FBs, at mean levels of 29.1 and $2,100 \mu \mathrm{g} / \mathrm{kg}$, respectively. Soybean samples presented mean levels of 1.5 and $70 \mu \mathrm{g} / \mathrm{kg}$ for AFs and FBs, respectively. Batches of broilers receiving feed containing FB levels higher than 1,000 $\mathrm{gg} / \mathrm{kg}$ had lower weight gain and higher mortality rates, while those fed rations with AFs equal or above the limit of quantification (LOQ) of the analytical method presented higher scores of histological changes in the liver. A dilution effect was observed for AFs and FBs from ingredients, especially corn, to feed during manufacture, whilst not enough to prevent losses in productivity. Results of this trial highlighted the need for strict control of mycotoxins in corn intended for broilers. Key words: mycotoxins, $A F B_{l}, F B_{l}$, broiler chickens, productivity.

Aflatoxinas e fumonisinas em rações de um sistema de produção de frangos de corte no estado de São Paulo, Brasil

RESUMO: $O$ objetivo do presente trabalho foi verificar a ocorrência de aflatoxinas (AFs) e fumonisinas (FBs) em ingredientes (milho e farelo de soja) e na ração de abate sobre a produtividade de uma empresa integradora de frangos de corte, bem como avaliar seus efeitos sobre produtividade de 20 lotes de frangos produzidos pela empresa e a histologia dos fígados dos frangos após o abate. As amostras de milho apresentaram as maiores frequências de AFs e FBs, em concentrações médias de 29,1 e 2.100 $\mu \mathrm{g} / \mathrm{kg}$, respectivamente. As amostras de farelo

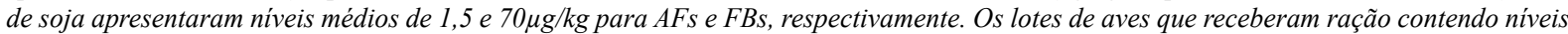
de FBs maiores que 1,000 $\mathrm{gg} / \mathrm{kg}$ apresentaram menor ganho de peso e maior percentual de mortalidade, enquanto que as que receberam ração com AFs iguais ou superiores ao limite de quantificação $(L Q)$ do método analítico apresentaram maior grau de alteração histopatológica no figado. Houve efeito de diluição de AFs e FBs dos ingredientes, especialmente o milho, à ração no processo de fabricação, porém não suficiente para evitar perdas na produtividade. Os resultados do estudo reforçam a necessidade do controle estrito de micotoxinas no milho destinado à alimentação de frangos de corte.

Palavras-chave: micotoxinas, $A F B_{l}, F B_{l}$, frangos de corte, produtividade.

\section{INTRODUCTION}

Mycotoxins are secondary metabolites produced by a range of toxigenic fungi that develop naturally in foodstuffs, which causes a great variety of toxic effects in several animal species (RICHARD, 2007). Broiler chicks are particularly sensitive to the adverse effects of mycotoxins in feed that was prepared with contaminated main ingredients, especially corn (OLIVEIRA et al., 2014). In Brazil, the most common toxigenic fungi reported in corn and corn-based feed included species from the genera Aspergillus and Fusarium (SANTURIO, 2000; AQUINO \& POTENZA, 2013), which produce the aflatoxins (AFs) and fumonisins (FBs), respectively. As a consequence, AFs and FBs are the most frequently reported mycotoxins in Brazilian corn and commercial feed for poultry (SOUZA et al., 2013). However, there is no regulation for mycotoxins in feed in Brazil, except for a recommended maximum value of $50 \mu \mathrm{g} / \mathrm{kg}$ of $\mathrm{AFs}$ in feed ingredients (MINISTÉRIO DA AGRICULTURA, 1988). Soybean meal is considered a low-risk product for AF or FB contamination (OLIVEIRA et al., 2014); although, other Fusarium toxins such as nivalenol and deoxynivalenol have been reported (MARTINELLI et al., 2004). MALLMANN et al. (2001) did not observe any positive sample of soybean meal from 
southern states in Brazil containing FBs, and there is no report on the occurrence of AFs in Brazilian soybean meal.

Twenty different types of AFs were identified; although, only $\mathrm{AFB}_{1}, \mathrm{AFB}_{2}, \mathrm{AFG}_{1}$ and $\mathrm{AFG}_{2}$ are frequently reported as natural contaminants of food products (HUSSEIN \& BRASEL, 2001). Toxic effects of AFs include carcinogenicity, mutagenicity, teratogenicity and hepatotoxicity (JAGER et al., 2013). In poultry production systems, the AFs negatively affect the body weight gain and feed conversion, and causes histological changes in the liver as well as immunosuppression and increased mortality rates (RICHARD, 2007). Twenty-eight structurally related FBs have been isolated and identified, although $\mathrm{FB}_{1}$, $\mathrm{FB}_{2}$ and $\mathrm{FB}_{3}$ are the most predominant form produced by the fungi (REISINGER et al., 2016). In poultry, FBs cause decreased feed consumption and body weight gain, increased relative weights of liver and kidney, and liver necrosis (HENRY et al., 2000; TESSARI et al., 2010).

The toxicological data available on the effects of AFs or FBs in broiler chickens are mostly based on experimental trials conducted at laboratory scale (ALLAMEH et al., 2005). However, there is no information on the health impacts of these mycotoxins under conditions of natural occurrence in the field, such as commercial poultry production units in Brazil. Thus, the present study aimed to determine the occurrence of AFs and FBs in the main feed ingredients (corn and soybean meal) and finishing feed of a broiler operation system, and evaluate their impact on the company's productivity.

\section{MATERIALS AND METHODS}

\section{Broiler operation system characteristics and sampling procedures}

The study was conducted in a broiler operation system located in the Southeast region of the State of São Paulo, which used the integration system composed by nearly 280 integrated farms to produce around 6,000 tons/month of finished products. The company produced the total feed required by the farms, using corn and soybean meal harvested in the Brazilian Mid-West region as main ingredients. In all integrated farms, the birds were vaccinated against Marek's disease (Fort Dogde ${ }^{\circledR}$ ) and Gumboro disease (CEVAC ${ }^{\circledR}$ IBD L) at hatchery and at 14 day-old, respectively.

The following types of samples were collected in the study, during manufacture of 17 batches of feed: feed ingredients (corn and soybean meal, $\mathrm{N}=17$ for each product) received by the company and stored in the feed production plant, finishing feed freshly prepared (supplied to animals from 41 to 48 days of age) $(\mathrm{N}=47)$, and finishing feed stored $(\mathrm{N}=47)$ for up to 10 days in 7 farms with housing capacity ranging from 9,000 to 39,000 birds. Composed samples $(2 \mathrm{~kg})$ were collected from of each product, and the number and weight of incremental samples collected from different points in the storage silos followed the recommendations of ISO 6497 (ISO, 2002). All samples were placed in polyethylene bags and sent to the laboratory for immediate analysis. The 17 batches of finishing feed were distributed to the 7 integrated farms of the company and used to produce 20 batches of broilers $(\mathrm{N}=4,000-5,000$ birds per batch).

\section{Analyses of aflatoxins and fumonisins}

Extraction and purification of corn, soybean meal and feed samples for determination of AFs $\left(\mathrm{AFB}_{1}, \mathrm{AFB}_{2}, \mathrm{AFG}_{1}\right.$ and $\left.\mathrm{AFG}_{2}\right)$ were performed using immuno affinity columns $\left(\mathrm{Neogen}^{\circledR}\right)$ as described by OLIVEIRA et al. (2008). For FBs (FB, $\mathrm{FB}_{2}$ ), solid phase extraction (SPE) columns (BondElut SAX) were used for extraction and purification according to BORDIN et al. (2014). The AFs and FBs were determined using a high performance liquid chromatography (HPLC) system, composed by a Shimadzu (Kyoto, Japan) 10VP liquid chromatograph, a 10 AXL fluorescence detector, a Shim-Pack CLC-ODS Sil column $(4.6$ X250mm, $5 \mu \mathrm{m})$ and a Shim-Pack pre-column (4X10mm, $5 \mu \mathrm{m}$ CLC G-ODS). Instrument set up, preparation of calibration curves, derivatization steps and chromatographic conditions for determination of AFs and FBs strictly followed the procedures as described by OLIVEIRA et al. (2008) and BORDIN et al. (2014). The retention times were approximately 4.2, 5.3, 7.6 and $9.5 \mathrm{~min}$. for $\mathrm{AFG}_{1}$ (converted to $\mathrm{AFG}_{2 \mathrm{a}}$ ), $\mathrm{AFB}_{1}$ (converted to $\mathrm{AFB}_{2 \mathrm{a}}$ ), $\mathrm{AFG}_{2}$ and $\mathrm{AFB}_{2}$, respectively. For $\mathrm{FB}_{1}$ and $\mathrm{FB}_{2}$, the retention times were approximately 9.5 minutes, respectively. The limits of detection (LOD) and limits of quantification (LOQ) were calculated based on signal: noise ratios of 3:1 and 10:1, respectively. The performances of the analytical methods were evaluated as previously described (OLIVEIRA et al., 2008; BORDIN et al., 2014).

Results reported in the finishing feed stored in the farms were categorized into four groups according to the levels of AFs (below and equal or above the LOQ value of the analytical method), and FBs (lower and equal or above $1,000 \mu \mathrm{g} / \mathrm{kg}$ ). 


\section{Productivity parameters}

During the study, 20 batches of broilers were raised in the 7 integrated farms evaluated until the age of 48 days, when they were sent to the company's slaughterhouse. At the time of slaughter of broilers of each batch from each farm, the following parameters were calculated by the company: Average daily weight gain $(\mathrm{g} /$ day $)=($ final weight-initial weight $) /$ period in days; Feed conversion $(\mathrm{g} / \mathrm{g})=$ Feed intake $(\mathrm{g}) /$ weight gain $(\mathrm{g})$; Production factor $=($ viability $\mathrm{x}$ average daily weight gain)/(feed conversionx 10); Mortality $(\%)=($ number of birds at start - number of birds at the end)x100/number of birds at start.

\section{Histological analysis}

In the slaughterhouse, samples of liver, kidney, heart and bursa of Fabricius from 2 birds per batch of broilers were collected, totaling 40 samples of each organ. Samples were fixed in formalin, embedded in paraffin, sectioned at $4 \mu \mathrm{m}$, and stained with hematoxylin and eosin stain for histopathology analysis (LUNA, 1968). Organs sections from all treatment groups were examined microscopically and individual sample numerical scores were reported using the following scoring system, based on the severity of the main mycotoxin-associated lesions (NEEFF et al., 2013): $0=$ Organ section unremarkable; $1=$ Lesions in organ section are compatible with mild mycotoxicosis, affecting less than $20 \%$ of the tissue; $2=$ Lesions in organ section are compatible with light mycotoxicosis, affecting $20 \%$ to $40 \%$ of the tissue; $3=$ Lesions in organ section are compatible with moderate mycotoxicosis, affecting $40 \%$ to $60 \%$ of the tissue; $4=$ Lesions in organ section are compatible with serious mycotoxicosis, affecting $60 \%$ to $80 \%$ of the tissue; and $5=$ Lesions in organ section are compatible with severe mycotoxicosis, affecting more than $80 \%$ of the tissue.

\section{Statistical analysis}

The 20 batches of broilers produced in the 7 farms evaluated were classified in four categories, according to the AF or FB levels reported in the finishing feed stored in the farms, as described earlier. The productivity parameters and histopathological scores within each AF or FB category were analyzed by the Student's t-Test, using the statistical package SAS 9.1 (SAS, 2004). The differences among means were considered significant at $\mathrm{P}<0.05$.

\section{RESULTS AND DISCUSSION}

The occurrence of AFs and FBs in samples of corn, soybean meal and finished feed (freshly prepared and stored in the farms) is presented in table 1. The frequency of samples containing quantifiable levels of AFs in corn samples (65\%) was similar to the value reported $(55 \%)$ in samples of freshly harvested maize in the State of São Paulo, with a highest concentration of $\mathrm{AFB}_{1}$ of $1,600 \mu \mathrm{g} / \mathrm{kg}$ (MACHINSKI et al., 2001). However, the mean value of total AFs for corn in the present study was $29.1 \pm 24.4 \mu \mathrm{g} / \mathrm{kg}$, which is below the recommended maximum value of $50 \mu \mathrm{g} / \mathrm{kg}$ of total AFs in feed ingredients in Brazil (MINISTÉRIO DA AGRICULTURA, 1988). The highest AF levels was reported in a corn sample containing $115.3 \mu \mathrm{g} / \mathrm{kg}$, and this was the only sample with concentration of total AFs above the Brazilian

Table 1 - Occurrence of aflatoxins in samples of corn, soybean meal, finishing feed freshly prepared and finishing feed stored in integrated farms of a broiler operation in São Paulo, Brazil.

\begin{tabular}{|c|c|c|c|c|c|}
\hline \multirow[t]{2}{*}{ Type of sample } & \multirow[t]{2}{*}{$N$} & \multicolumn{2}{|c|}{------------------'Total AFs ${ }^{1}$--------------- } & \multicolumn{2}{|c|}{ 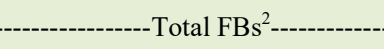 } \\
\hline & & $N(\%)$ & Mean $(\mu \mathrm{g} / \mathrm{kg})$ & $n(\%)$ & Mean $(\mu \mathrm{g} / \mathrm{kg})$ \\
\hline Corn & 17 & $11(65)$ & $29.1 \pm 24.4$ & $17(100)$ & $2,070 \pm 1,550$ \\
\hline Soybean meal & 17 & $1(6)$ & 1.5 & $10(59)$ & $70 \pm 30$ \\
\hline Finishing feed (freshly prepared) & 47 & $10(21)$ & $2.9 \pm 3.1$ & $41(87)$ & $1,260 \pm 890$ \\
\hline Finishing feed (stored in farm) & 47 & $8(17)$ & $3.8 \pm 4.8$ & $42(89)$ & $1,310 \pm 1,050$ \\
\hline
\end{tabular}

$N$ : Number of samples analyzed.

$n$ : number of samples with levels equal or above the limit of quantification $(0.5 \mu \mathrm{g} / \mathrm{kg}$ for each aflatoxin, and $30 \mu \mathrm{g} / \mathrm{kg}$ for each fumonisin).

${ }^{1}$ Sum of aflatoxins $B_{1}, B_{2}, G_{1}$ and $G_{2}$.

${ }^{2}$ Sum of fumonisins $\mathrm{B}_{1}$ and $\mathrm{B}_{2}$. 
recommended limit. ROCHA et al. (2009) reported a lower frequency $(10 \%)$ of freshly harvested corn contaminated with AF, at much higher levels (up to $1,906 \mu \mathrm{g} / \mathrm{kg}$ ) than those observed in the present study.

The high frequency of FBs $(100 \%)$ found in corn samples is consistent with previous studies demonstrating high occurrence rates of FBs in commercially available corn in Brazil (MORENO et al., 2009; ROCHA et al., 2009; QUEIROZ et al., 2012). In our study, the maximum concentration of total FBs was observed in a corn sample containing $3,900 \mu \mathrm{g} / \mathrm{kg}$, which is lower than the highest level $(6,450 \mu \mathrm{g} / \mathrm{kg})$ reported by QUEIROZ et al. (2012) in corn from Minas Gerais State. Much higher FB levels (up to $18,740 \mu \mathrm{g} / \mathrm{kg}$ ) were observed by VAN DER WESTHUIZEN et al. (2003) in corn from Santa Catarina State, at mean concentration $3,210 \mu \mathrm{g} / \mathrm{kg}$. Soybean meal samples presented lower frequency $(59 \%)$ and mean level $(70 \pm 30 \mu \mathrm{g} / \mathrm{kg})$ of total FBs.

Compared with corn, soybean meal samples had much lower frequency and levels of AFs or FBs than in corn, hence indicating its lower relevance as a source of mycotoxin contamination in the feed manufacture. MALLMANN et al. (2001) did not reported detectable levels of FBs in soybean meal samples from southern states in Brazil, which is in agreement with data reported here. Furthermore, samples of finishing feed also had lower AF or FB frequency and levels when compared with corn, which may suggest a dilution of the mycotoxin content from corn to feed during manufacture. ALLAMEH et al. (2005) also observed that using corn containing $1,000 \mu \mathrm{g} / \mathrm{kg}$ of $\mathrm{AFB}_{1}$ as ingredient resulted in the concentration of $650 \mu \mathrm{g} / \mathrm{kg}$ in the feed. A similar reduction in the frequency of positive samples was reported in a study conducted in Egypt by ABDALLAH et al. (2017), who detected AFB in $16 \%$ of corn and $4 \%$ of feed samples analyzed, at mean levels of 4.8 and $5.3 \mu \mathrm{g} / \mathrm{kg}$, respectively. In our study, the frequencies and levels of AFs were similar in freshly prepared feed and feed available in the farms, thus indicating good storage conditions of feed in the farms evaluated. Our result for FBs is also in agreement with those reported by SOUZA et al. (2013), who observed median FB levels of $1,840 \mu \mathrm{g} /$ $\mathrm{kg}$ and $239 \mu \mathrm{g} / \mathrm{kg}$ in samples of corn (before the factory processing) and poultry feed (after the factory processing), respectively. SOUZA et al. (2013) explained that the average contamination levels in poultry feed samples were lower due to the processing or the addition of other ingredients beside corn.

Productivity parameters of batches of broiler chicks categorized according to quantifiable levels of $\mathrm{AFs}(\mathrm{AFs}<\mathrm{LOQ}, \mathrm{AFs} \geq \mathrm{LOQ})$ or $\mathrm{FBs}$ $(\mathrm{FBs}<1,000 \mu \mathrm{g} / \mathrm{kg}, \mathrm{FBs} \geq 1,000 \mu \mathrm{g} / \mathrm{kg})$ in the finishing feed stored in the farms are presented in table 2 . No effect $(\mathrm{P}>0.05)$ was observed in the feed conversion and production factor of broiler categories. However, birds fed rations containing with $\mathrm{FBs} \geq 1,000 \mu \mathrm{g} / \mathrm{kg}$ in the diet lower $(\mathrm{P}<0.05)$ weight gain $(56.8 \pm 2.6 \mathrm{~g} /$ day) and higher mortality rate $(6.1 \pm 2.3 \%)$, when compared with the $\mathrm{FBs}<1,000 \mu \mathrm{g} / \mathrm{kg}$ category. Birds receiving $\mathrm{FBs} \geq 1,000 \mu \mathrm{g} / \mathrm{kg}$ in the diet had approximately $4 \%$ lower weight gain when compared to the $\mathrm{FBs}<1,000 \mu \mathrm{g} / \mathrm{kg}$ group. RAUBER et al. (2013) observed that negative effects on performance of broilers receiving experimental feeds containing $100,000 \mu \mathrm{g} / \mathrm{kg}$, which is much higher than the maximum FB level reported in the feed of the present study $(3,950 \mu \mathrm{g} / \mathrm{kg})$.

Table 3 presents the histopathological scores observed in the organs of batches of broiler chicks categorized according to LOQ for AFs or FBs in the finishing feed stored in the farms. No

Table 2 - Productivity parameters of 20 batches of broiler chicks categorized according to quantifiable levels of aflatoxins (AFs) or fumonisins (FBs) in the finishing feed stored in the farms.

\begin{tabular}{lccc}
\hline Broiler batch category & Weight gain (g/day) & Feed conversion $(\mathrm{g} / \mathrm{g})$ & Production factor $^{1}$ \\
\hline $\mathrm{AFs}<\mathrm{LOQ}^{2}(N=12)$ & $58.3 \pm 2.4^{\mathrm{a}}$ & $1.8 \pm 0.1^{\mathrm{a}}$ & $305.7 \pm 22.5^{\mathrm{a}}$ \\
$\mathrm{AFs} \geq \mathrm{LOQ}(N=8)$ & $57.7 \pm 3.0^{\mathrm{ab}}$ & $1.9 \pm 0.1^{\mathrm{a}}$ & $296.7 \pm 31.8^{\mathrm{a}}$ \\
$\mathrm{FBs}<1,000 \mu \mathrm{g} / \mathrm{kg}(N=10)$ & $59.1 \pm 2.4^{\mathrm{a}}$ & $1.8 \pm 0.1^{\mathrm{a}}$ & $3.1 \pm 1.7^{\mathrm{ab}}$ \\
$\mathrm{FBs} \geq 1,000 \mu \mathrm{g} / \mathrm{kg}(N=10)$ & $56.8 \pm 2.6^{\mathrm{b}}$ & $1.9 \pm 0.1^{\mathrm{a}}$ & $29.5^{\mathrm{a}}$ \\
\hline
\end{tabular}

${ }^{\mathrm{a}-\mathrm{b}}$ Values within each column with no common superscript differ significantly $(P<0.05)$.

${ }^{1}$ Calculated as follows: Production factor=(viability $\mathrm{x}$ average daily weight gain $) /($ feed conversion $\mathrm{x} 10)$.

${ }^{2} \mathrm{LQ}$ : Limit of quantification $\left(0.5 \mu \mathrm{g} / \mathrm{kg}\right.$ for $\mathrm{AFB}_{1}, \mathrm{AFB}_{2}, \mathrm{AFG}_{1}$ or $\left.\mathrm{AFG}_{2}\right)$. 
Table 3 - Histopathological scores observed in the organs of 20 batches of broiler chicks categorized according to quantifiable levels of aflatoxins (AFs) or fumonisins (FBs) in the finishing feed stored in the farms.

\begin{tabular}{|c|c|c|c|c|}
\hline \multirow[t]{2}{*}{ Lot category } & \multicolumn{4}{|c|}{---Scores ${ }^{1}--$} \\
\hline & Liver & Kidney & Heart & Bursa \\
\hline AFs $<\mathrm{LQ}^{2}(N=12)$ & $0.3 \pm 0.1^{\mathrm{b}}$ & $0.1 \pm 0.1^{\mathrm{a}}$ & $0.2 \pm 0.1^{\mathrm{a}}$ & $0.3 \pm 0.1^{\mathrm{a}}$ \\
\hline $\mathrm{AFs} \geq \mathrm{LQ}(N=8)$ & $1.2 \pm 0.2^{\mathrm{a}}$ & $0.3 \pm 0.1^{\mathrm{a}}$ & $0.3 \pm 0.1^{\mathrm{a}}$ & $0.2 \pm 0.1^{\mathrm{a}}$ \\
\hline $\mathrm{FBs}<1,000 \mu \mathrm{g} / \mathrm{kg}(N=10)$ & $0.3 \pm 0.1^{\mathrm{b}}$ & $0.2 \pm 0.1^{\mathrm{a}}$ & $0.2 \pm 0.1^{\mathrm{a}}$ & $0.3 \pm 0.2^{\mathrm{a}}$ \\
\hline $\mathrm{FBs} \geq 1,000 \mu \mathrm{g} / \mathrm{kg}(N=10)$ & $0.4 \pm 0.2^{\mathrm{b}}$ & $0.2 \pm 0.1^{\mathrm{a}}$ & $0.4 \pm 0.1^{\mathrm{a}}$ & $0.3 \pm 0.1^{\mathrm{a}}$ \\
\hline
\end{tabular}

${ }^{\mathrm{a}-\mathrm{b}}$ Values within each column with no common superscript differ significantly $(P<0.05)$.

${ }^{1}$ Scores of histopathological changes: $0=$ no significant change, $1=$ mild changes; $2=$ light changes; $3=$ moderate changes; $4=$ serious changes; $5=$ severe changes (NEEFF et al., 2013).

${ }^{2} \mathrm{LQ}$ : Limit of quantification $\left(0.5 \mu \mathrm{g} / \mathrm{kg}\right.$ for $\mathrm{AFB}_{1}, \mathrm{AFB}_{2}, \mathrm{AFG}_{1}$ or $\left.\mathrm{AFG}_{2}\right)$.

macroscopic alterations in the organs collected were noted, and no differences $(\mathrm{P}>0.05)$ were found in the scores of kidneys, heart and Bursa of Fabricius from broilers within categories. However, a higher score $(1.2 \pm 0.2)$ was observed in liver sections of broilers from the AFs $\geq$ LOQ category, which are consistent with mild lesions including discrete steatosis, proliferation of cells of the bile ducts and periportal inflammatory infiltrate during aflatoxicosis (HUSSAIN et al., 2010). These results confirmed that even low AF levels in feed can cause negative effects in broilers, hence indicating the need for a revision of the recommended maximum value of total AFs $(50 \mu \mathrm{g} / \mathrm{kg})$ in feed ingredients in Brazil (MINISTÉRIO DA AGRICULTURA, 1988). In agreement with our results, JONES et al. (1982) observed in the United States that low AF levels in corn, feed immediately after production and feed stored in the farm $(1.2,6.0$ and $8.8 \mu \mathrm{g} /$ $\mathrm{kg}$, respectively) were associated with productivity losses in apparently healthy broilers.

In conclusion, corn samples presented higher frequency of AFs (65\%) and FBs (100\%), at mean levels of $29.1 \mu \mathrm{g} / \mathrm{kg}$ and $2.1 \mathrm{mg} / \mathrm{kg}$, respectively. Among the other feed ingredients, soybean meal presented the lowest frequencies for AFs (6\%) and FBs (59\%). Birds receiving feed containing FB levels equal or above the quantification limit ( $\geq$ LOQ) of the analytical method had lower weight gain and higher mortality rates, hence indicating losses in the company's productivity. Additionally, birds fed rations with $\mathrm{AFs} \geq \mathrm{LOQ}$ presented higher scores of histological changes in the liver. A dilution effect was observed for AFs and FBs from corn to feed during manufacture, whilst not enough to prevent losses in productivity. Results of this trial highlight the need for strict control of mycotoxins in corn intended for broilers.

\section{ACKNOWLEDGEMENTS}

The authors would like to thank the Conselho Nacional de Desenvolvimento Científico e Tecnológico (CNPq) -grants no. 562334/2008-4 and 143507/2008-7, for financial support and fellowships. This study was financed in part by the Coordenação de Aperfeiçoamento de Pessoal de Nível Superior Brasil (CAPES) - Finance Code 001.

\section{DECLARATION OF CONFLICTING INTERESTS}

The authors declare no conflict of interest. The founding sponsors had no role in the design of the study; in the collection, analyses, or interpretation of data; in the writing of the manuscript, and in the decision to publish the results.

\section{AUTHORS' CONTRIBUTIONS}

EK and CO conceived and designed experiments. EK performed the experiments and carried out the lab analyses. $\mathrm{CO}$ supervised and coordinated the animal experiments and lab analyses. CC performed statistical analyses and interpretation of experimental data. LF and RU retrieved the scientific literature and prepared the draft of the manuscript. All authors critically revised the manuscript and approved the final version.

\section{REFERENCES}

ABDALLAH, M.F. et al. Occurrence of multiple mycotoxins and other fungal metabolites in animal feed and maize samples from Egypt using LC-MS/MS. Journal of the Science of Food and Agriculture, v.97, n.13, p.4419-4428, 2017. Available from: $<$ https://onlinelibrary.wiley.com/doi/full/10.1002/jsfa.8293>. Accessed: Jan. 31, 2019. doi: 10.1002/jsfa.8293 
ALLAMEH, A. et al. Evaluation of biochemical and production parameters of broiler chicks fed ammonia treated aflatoxin contaminated maize grains. Animal Feed Science and Technology, v.122, p.289-301, 2005. Available from: <https:// www.sciencedirect.com/science/article/pii/S0377840105001124>. Accessed: Jan. 31, 2019. doi: 10.1016/j.anifeedsci.2005.03.005.

AQUINO, S.; POTENZA, M.R. Análise da micobiota associada à entomofauna em rações a granel para animais domésticos. Arquivos do Instituto Biológico, v.80, p.243-247, 2013. Available from: $<$ http://www.scielo.br/scielo.php?script=sci arttext\&pid=S1808$16572013000200016 \& \operatorname{lng}=$ en\&nrm $=\mathrm{iso} \& \operatorname{tn} \mathrm{l}=\mathrm{p}=\mathrm{pt}>$. Accessed: Jan. 31, 2019. doi: 10.1590/S1808-16572013000200016

BORDIN, K. et al. Assessment of dietary intake of fumonisin B in São Paulo, Brazil. Food Chemistry, v.155, p.174-178, 2014. Available from: <https://www.sciencedirect.com/science/article/ pii/S0308814614000788?via\%3Dihub>. Accessed: Jan. 31, 2019. doi: 10.1016/j.foodchem.2014.01.057.

HENRY, M.H. et al. The toxicity of purified fumonisin $\mathrm{B}_{1}$ in broiler chicks. Poultry science, v.79, n.10, p.1378-1384, 2000. Available from: $<$ https://academic.oup.com/ps/article/79/10/1378/1530685>. Accessed: Jan. 31, 2019. doi: 10.1093/ps/79.10.1378.

HUSSEIN, H.; BRASEL, J. Toxicity, metabolism and impact of mycotoxins on human and animals. Toxicology, v.167, p.101-134, 2001. Available from: <https:/www.sciencedirect.com/science/ article/pii/S0300483X01004711?via\%3Dihub>. Accessed: Jan. 31, 2019. doi: 10.1016/S0300-483X(01)00471-1.

HUSSAIN, Z. et al. Residues of aflatoxin $\mathrm{B}_{1}$ in broiler meat: Effect of age and dietary aflatoxin $B_{1}$ levels. Food and Chemical Toxicology, v.48, p.3304-3307, 2010. Available from: <https:// www.sciencedirect.com/science/article/pii/S0278691510005260>. Accessed: Jan. 31, 2019. doi: 10.1016/j.fct.2010.08.016.

ISO. Animal feeding stuffs - Sampling. International Standard ISO 6497, 2002.

JAGER,A.V. et al.Assessment of aflatoxin intake in São Paulo, Brazil. Food Control, v.33, n.1, p.87-92, 2013. Available from: <https:// www.sciencedirect.com/science/article/pii/S0956713513000923>. Accessed: Jan. 31, 2019. doi: 10.1016/j.foodcont.2013.02.016.

JONES, F.T. et al. Association of low levels of aflatoxin in feed with productivity losses in commercial broiler operations. Poultry Science, v.61, p.861-868, 1982. Available from: $<$ https://academic. oup.com/ps/article-abstract/61/5/861/1471366?redirectedFrom=fu lltext>. Accessed: Jan. 31, 2019. doi: 10.3382/ps.0610861.

LUNA, G.L. Manual of histologic staining methods of the armed forces. $3^{\text {rd }}$ ed. New York : McGraw-Hill, 1968. 258p.

MACHINSKI, M. et al. Aflatoxins, ochratoxin A and zearalenone in Brazilian corn cultivars. Journal of the Science of Food and Agriculture, v.81, n.10, p.1001-1007, 2001. Available from: $<$ https://onlinelibrary.wiley.com/doi/full/10.1002/jsfa.882>. Accessed: Jan. 31, 2019. doi: 10.1002/jsfa.882.

MALLMANN, C.A. et al. Fumonisin B levels in cereals and feeds from southern Brazil. Arquivos do Instituto Biológico, v.68, n.1, p.41-45, 2001. Available from: <http://www.biologico.sp.gov.br/ uploads/docs/arq/V68_1/8.pdf >. Accessed: Jan. 31, 2019.

MARTINELLI et al. Soybean pod blight and root rot caused by lineages of the Fusarium graminearum and the production of mycotoxins. Fitopatologia Brasileira, v.29, n.5, p.492-498, 2004. Available from: <http://www.scielo.br/scielo.php?script=sci artt ext\&pid=S0100-41582004000500004>. Accessed: Jan. 31, 2019. doi: 10.1590/S0100-41582004000500004.

MINISTÉRIO DA AGRICULTURA. Portaria $\mathrm{n}^{\circ}$ 07, de 09 de novembro de 1988. Diário Oficial da União 21.968, 1988.

MORENO, E.C. et al. Co-occurrence of mycotoxins in corn samples from the Northern region of Paraná State, Brazil. Food Chemistry, v.116, n.1, p.220-226, 2009. Available from: <https:// www.sciencedirect.com/science/article/pii/S0308814609002258>. Accessed: Jan. 31, 2019. doi: 10.1016/j.foodchem.2009.02.037.

NEEFF, D.V. et al. In vitro and in vivo efficacy of a hydrated sodium calcium aluminosilicate to bind and reduce aflatoxin residues in tissues of broiler chicks fed aflatoxin B. Poultry Science, v.92, n.1, p.131-137, 2013. Available from: <https://academic.oup. com/ps/article/92/1/131/1553694>. Accessed: Jan. 31, 2019. doi: $10.3382 /$ ps.2012-02510

OLIVEIRA, C.A.F. et al. Aflatoxins and cyclopiazonic acid in feed and milk from dairy farms in São Paulo, Brazil. Food Additives \& Contaminants: Part B, v.1, n.2, p.147-152, 2008. Available from: <https://www.tandfonline.com/doi/ abs/10.1080/02652030802382865>. Accessed: Jan. 31, 2019. doi: $10.1080 / 02652030802382865$.

OLIVEIRA, C.A.F. et al. Animal health: mycotoxins. In: VANALFEN N. Encyclopedia of Agriculture and Food Systems. San Diego: Elsevier, 2014. Chap. 200, p.358-377. Available from: $<$ https://www. sciencedirect.com/science/article/pii/B978044452512300200X>. Accessed: Jan. 31, 2019. doi: 10.1016/B978-0-444-52512-3.00200-X.

QUEIROZ, V.A.V. et al. Occurrence of fumonisins and zearalenone in maize stored in family farm in Minas Gerais, Brazil. Food Control, v.28, n.1, p.83-86, 2012. Available from: $<$ https://www. sciencedirect.com/science/article/pii/S0956713512002125>. Accessed: Jan. 31, 2019. doi: 10.1016/j.foodcont.2012.04.039.

RAUBER, R. H. et al. Effects of fumonisin B on selected biological responses and performance of broiler chickens. Pesquisa Veterinária Brasileira, v.33, p.1081-1086, 2013. Available from: $<$ http://www.scielo.br/scielo.php?script=sci_arttext\&pid=S0100736X2013000900006>. Accessed: Jan. 31, 2019. doi: 10.1590/ S0100-736X2013000900006.

REISINGER, N. et al. Fumonisin $\mathrm{B}_{1}\left(\mathrm{FB}_{1}\right)$ induces lamellar separation and alters sphingolipid metabolism of in vitro cultured hoof explants. Toxins, v.8, n.4, p.1-11, 2016. Available from: $<$ https://www.mdpi.com/2072-6651/8/4/89>. Accessed: Jan. 31, 2019. doi: $10.3390 /$ toxins 8040089 .

RICHARD, J.L. Some major mycotoxins and their mycotoxicoses An overview. International Journal of Food Microbiology, v.119, n.1-2, p.3-10, 2007. Available from: <https://www.sciencedirect. com/science/article/pii/S0168160507003790?via\%3Dihub $>$. Accessed: Jan. 31, 2019. doi: 10.1016/j.ijfoodmicro.2007.07.019.

ROCHA, L.O. et al. Mycoflora and co-occurrence of fumonisins and aflatoxins in freshly harvested corn in different regions of Brazil. International Journal of Molecular Sciences, v.10, n.11, p.5090-5103, 2009. Available from: <https://www.mdpi. com/1422-0067/10/11/5090>. Accessed: Jan. 31, 2019. doi: 10.3390/ijms10115090. 
SANTURIO, J.M. Micotoxinas e micotoxicoses na avicultura. Revista Brasileira de Ciência Avícola, v.2, p.1-12, 2000. Available from: $<$ http://www.scielo.br/scielo.php?script=sci_arttext\&pid=S1516635X2000000100001>. Accessed: Jan. 31, 2019. doi: 10.1590/S1516$635 \times 2000000100001$.

SAS. SAS INSTITUTE 9.1 Users guide. Carey: SAS Institute Inc. 2004. 1040p.

SOUZA, M.D.L.M. et al. Cooccurrence of mycotoxins in maize and poultry feeds from Brazil by liquid chromatography/tandem mass spectrometry. The Scientific World Journal, v.2013, Article ID 427369, 2013. Available from: <https://www.hindawi. com/journals/tswj/2013/427369/>. Accessed: Jan. 31, 2019. doi: $10.1155 / 2013 / 427369$.

TESSARI, E.N.C. et al. Effects of aflatoxin $\mathrm{B}_{1}$ and fumonisin $\mathrm{B}_{1}$ on blood biochemical parameters in broilers. Toxins, v.2, n.4, p.453-460, 2010. Available from: $<$ https://www.mdpi.com/2072-6651/2/4/453>. Accessed: Jan. 31, 2019. doi: 10.3390/toxins2040453.

VAN DER WESTHUIZEN, L. et al. Fumonisin contamination and Fusarium incidence in corn from Santa Catarina, Brazil. Journal of Agricultural and Food Chemistry, v.51, n.18, p.5574-5578, 2003. Available from: <https://pubs.acs.org/doi/abs/10.1021/ jf034298z>. Accessed: Jan. 31, 2019. doi: 10.1021/jf034298z. 